\title{
The Customer Awareness and Intention of Syariah Bank:The Role of Marketing Communications
}

\author{
Roslina $^{1}$, Habibullah Jimad ${ }^{2}$ \\ \{roslina@feb.unila.ac.id ${ }^{1}$, habibullah.jimad@feb.unila.ac.id ${ }^{2}$ \} \\ Faculty of Economics and Business, University of Lampung, Jl. Sumantri Brojonegoro, Bandar \\ Lampung, Indonesia ${ }^{1}$, \\ Faculty of Economics and Business, University of Lampung, J1. Sumantri Brojonegoro, Bandar \\ Lampung, Indonesia ${ }^{2}$
}

\begin{abstract}
A small number of Muslims who use Syariah banks, indicating that there are still many Muslim communities in Indonesia who do not understand the nature of Syariah banks. The purpose of this research is to examine the effect of marketing communication on the awareness and intention of customers of Syariah banks. This study used a survey method with college student respondents in Bandar Lampung. The sample was taken using non-probability sampling. Data analysis was performed using SEM. The results showed that marketing communications able to provide information to students were advertising (advertisements, brochures, signboards, and banners) and direct marketing (websites Syariah bank). Marketing communication affects customer intention to use Syariah bank products and awareness partially mediating the effect of marketing communication on customer intention to use Syariah bank products. This research is important for policymakers at Syariah banks to determine marketing communication strategies, especially for millennials.
\end{abstract}

Keywords: Customer awareness, customer intention, marketing communication, Syariah banks.

\section{Introduction}

Syariah banks are categorized as banks that have followed Islamic law because their operational activities and products are developed based on the Qur'an and the hadiths of the Prophet SAW. The increasing number of people who are aware of the halalness of a product provides opportunities for Syariah banks to continue to grow a large number of Muslim communities in Indonesia makes the opportunity for the development of Syariah banks in Indonesia even greater. In 2015, the number of Syariah banking customers in Indonesia reached more than 18 million customers [1]. When compared with the total population of Indonesia who is Muslim, the number of customers of Syariah banks is only 10\%. The disproportionate number of Muslims with the number of users of Syariah banks indicates that there are still many Muslim communities in Indonesia who do not understand the nature of Syariah banks. The role of the government also greatly determines the growth of Syariah banks, given that the growth of Syariah banks in Malaysia and countries in the Middle East cannot be separated from the role of the government. The existence of an assumption that profit sharing is not different from interest, banking products, and services that are considered to be still not good, as well as the 
existence of terms that use Arabic in Syariah banks, are some of the factors that cause a lack of public interest in using Syariah bank products [2]-[4].

Several previous studies have shown the importance of marketing communication to build awareness of Syariah banks, [5] shows that a lack of understanding of the principles of Islamic finance makes consumers unwilling to use Syariah banking products if credit facilities are not available, or if the bank shares the losses as large as the bank's profits. Research [6] shows that imperfections in communicating bank products and services will lead to a low understanding of Syariah banks and the uniqueness of Syariah banking products and services. Research conducted by [7] shows that proper marketing and promotion of Islamic financial products and services will help to increase the goodwill and reputation of Syariah banks. Research conducted by [8] on the role of public relations to promote Islamic products globally shows that advertising and activities are Corporate Social Responsibility important to be used by companies, while public relations play a role in rectifying incorrect perceptions about Syariah banks products globally.

Research on marketing communication at Syariah banks is very important considering that there are still few studies that discuss marketing communication and its impact on consumer awareness in Syariah banking. This research is useful for stakeholders to find out the most effective marketing communications to educate the younger generation and increase their awareness and understanding of Syariah banking products and services so that they are interested in using Syariah banks. Lack of research on marketing communications can lead to failure of Syariah banks to obtain additional funds from third parties/customers due to their lack of understanding of Syariah banks, the slower growth of Syariah banks, low market share, a poor image of Syariah banks, and unfamiliarity of the Muslim community with Syariah banks which results in low intention to use Syariah banking services.

\section{Literature Review}

\subsection{Marketing Communication}

Marketing communication is a means for companies, directly or indirectly, to inform a product, remind, and even persuade consumers about the products and brands being sold [9]. There is a debate about the use of advertising in Islam, advertising is generally considered unethical because it describes something more than what it is [10]. The process of promoting products in Islam is limited by certain sharia norms and principles. Communication through advertisements and other promotional must be accurate and truly represent the product or service being advertised, not coercive, and based on Islamic values [10]-[12].

Syariah banks can use television, radio, magazines, posters, banners, and even social media to promote their products and services as a communication channel to build consumer awareness. The responsibility of communicating Syariah banks can be carried out by mosque imams by educating the public about banks that are following Islamic principles [11]. Syariah banks can also use a marketing communication mix which consists of eight main models: (1) advertising, (2) sales promotion, (3) events and experiences, (4) public relations and publicity, (5) direct marketing, (6) interactive marketing, (7) word-of-mouth marketing, (8) personal selling [13]. Research conducted by [14] on marketing activities carried out in the Syariah bank industry in Indonesia shows that the more frequent advertisements that respondents see, the more they will remember the bank and the more positive their opinion on the bank.

H1. Marketing communication affects brand awareness. 


\subsection{Brand Awareness}

Brand awareness refers to the strength of the brand in the minds of consumers, namely the ability of potential buyers to recognize or remember a brand with certain products used by consumers [15], [16]. Brand awareness is very important for consumers who buy products for the first time [15]. Consumer brand awareness will arise when consumers receive information through effective marketing communication channels because it can reduce the risk of using the product [17]. Brand awareness consists of brand recognition and brand recall [9], [18]. Brand recognition is related to the ability of consumers to recognize a brand both visually and verbally after being exposed to marketing communications by the company [18], [19], brand recall is the ability of consumers to recall a brand when given a product category [19]. In a buying situation where the brand is not known, brand recognition will be experienced first by consumers and then brand recall [18].

\subsection{Purchase Intention}

Purchase intention is the possibility that a customer will buy a certain product [20]. Theory Reasoned Action predicts consumer buying behavior by measuring their intention to buy before they make a purchase (Keller, 2013). Theory of Planned Behavior (TPB) which is a refinement of Theory Reasoned Action. In this theory, purchasing behavior is related to processes that indirectly affect behavior, namely attitude, subjective norms, and perceived behavioral control. Theory of Planned Behavior describes the relationship between attitudes, subjective norms, and perceived behavioral control that affects a person's intention to behave [21].

\subsection{Hierarchy of Effect (HOE)}

The hierarchy-of-effects models originally developed for communication and advertising and can be better understood in the marketing communication decision process [22]. The hierarchical model that is widely used is the model stated by Lavidge and Steiner which consists of six stages: awareness, knowledge, liking, preference, conviction, purchase [23]. In advertising, hierarchies also appear in the form of the acronym AIDA (attention, interest-desireaction) which is widely used in the marketing and advertising literature[22], [23]. Research conducted by [7] shows that proper marketing and promotion of Islamic financial products and services will help to increase the goodwill and reputation of Syariah banks. Based on this, the research hypothesis is formulated:

H2: Marketing communication affects purchase intention.

H3: Brand awareness mediates the effect of marketing communication on purchase intention

\section{Methodology and Data Analysis}

This study used quantitative research with a survey method. The research sample was taken using nonprobability sampling. The number of samples in this study was 300, it is sufficient to analyze using SEM [24]. Respondents in this study were college students in the city of Bandar Lampung. Data analysis was performed using Structural Equation Modeling (SEM).

\section{Research Result and Discussion}

The validity test was carried out using factor analysis, showing that the value factor loading for all statement items was greater than 0.5 so that all statement items were declared valid. The results of the reliability test showed that the Cronbach's alpha value was greater than 0.7 so that 
all research variables were reliable. Respondents in this study were 300 students from eleven universities in Bandar Lampung. The respondents' age is majority around 20-22 years old (59.7\%), in general, they are sitting in four to eight semesters in higher education. The largest respondent in this study was female (65\%). Most of the respondents know about Syariah banks $(91 \%)$ and have received information about Syariah banks (71\%) from lectures, seminars, advertisements, family, or from Syariah bank websites. However, most respondents $(68 \%)$ have never used the services of a Syariah bank, either for transfers, paying tuition fees, or other transactions.

\subsection{Feasibility Test Research Model}

Test the feasibility of the model (goodness-of-fit) shows how well the model is determined to reproduce the observed covariance matrix between items indicator. Model feasibility tests can use absolute fit indices, incremental fit indices, and parsimony indices [24].

Tabel 1. Model Conformity Test Results

\begin{tabular}{cccc}
\hline Criteria Index Size & Reference Value & Results & Criteria \\
\hline CMIN & $\leq 3$ & 2.753 & Good \\
GFI & $\geq 0.9$ & 0.73 & Marginal \\
RMSEA & $>0.03-0.08$ & 0.08 & Good \\
TLI & $\geq 0.90$ & 0.713 & Marginal \\
CFI & $\geq 0.90$ & 0,782 & Marginal \\
\hline
\end{tabular}

Based on the results in table 1, it can be seen that several feasibility values (GFI, TLI, CFI, AGFI) are below the set reference value, but are still within the required range, which is between the values 0 and 1 . Thus it can be stated that the overall value of the feasibility of the model in this study is good because it meets the predetermined criteria.

\subsection{Mediation Test}

The mediation effect is created when a third variable or construct affects two other related constructs. The mediator explains the relationship between the two original constructs [24].

Table 2. Results of Mediation

\begin{tabular}{|c|c|c|c|c|c|c|}
\hline $\begin{array}{l}\text { Beta } \\
\text { estimates }\end{array}$ & $\mathrm{SE}$ & $\mathrm{CR}$ & P-value & Results & Conclusion & \\
\hline \multicolumn{7}{|l|}{ Before mediation } \\
\hline $\begin{array}{l}\text { Intention }(\mathrm{C})<--- \text { Marketing } \\
\text { Communication (A) }\end{array}$ & 0.451 &, 084 & 5,368 & $* * *$ & Significant & \\
\hline \multicolumn{7}{|l|}{ After mediation } \\
\hline $\begin{array}{l}\text { Intention }(\mathrm{C})<--- \text { Marketing } \\
\text { Communication }(\mathrm{A})\end{array}$ & & $0.106,054$, & 1.963 & 040 & Significant & supported \\
\hline $\begin{array}{l}\text { Awareness (B) <--- Marketing } \\
\text { Communication (A) }\end{array}$ & & $0.176,041$ & 4.310 & $* * *$ & Significant & supported \\
\hline
\end{tabular}

The results in Table 2 show that before mediation, the direct effect of marketing communication on customer intention in Syariah banks is significant $(\beta=0.451, \mathrm{p}$-value $=0.000)$. After mediation by adding the awareness variable, the beta value decreased $(\beta=0.106, p$-value $=$ 0.040 ) but the effect of marketing communication on intention was still significant. Thus it can be stated that the awareness variable mediates partially (partial mediation). 
Students are a potential segment to be developed by banks around the world because after they graduate, they can make choices for banks based on several criteria they believe [25]. The results also show that marketing communications affect brand awareness. Advertising and other promotional tools aim to convey messages to customers about the products offered by an organization. Consumers will not use a product if they are not aware of it, so brand awareness is a common communication goal for all promotional strategies [26]. Advertising and other promotional tools are declared effective if they can create customer awareness [27]. Advertising is a medium that is expected to have the greatest influence on brand awareness, although publicity, personal selling, and sales promotion can also increase awareness [26], [28].

Most of the marketing communication media for Syariah banks that are often seen and read by students are advertisements, brochures, banners, bank signboards, advertisements in print media, and Syariah bank websites. This shows that advertising is a medium that provides a lot of information to students about Syariah banks. However, other marketing communication media, such as events, seminars, sales promotions also provide information about Syariah banks to students. The results of this study are in line with research conducted by [27] which shows that marketing communications such as direct marketing, seminars, and carnivals conducted by Islamic financial institutions affect the understanding of Islamic financial institutions. In social media, consumers who initially participate passively in marketing become active creators and influencers, transfer the power of the brand directly to consumers because of two-way communication [29]. The research conducted also shows that brand awareness partially mediates the purchase intention of Syariah bank customers. The results of this study are in line with the results of research conducted by [22] which examined the impact of social media on brand awareness, activity word of mouth, and purchase intention. Only $27.7 \%$ of respondents stated that Syariah banks emerged as the main choice when using Syariah bank products. These results indicate that most respondents are at the lowest awareness stage, namely the cognitive stage. At this stage, it is necessary to repeat marketing communication messages so that students can remember the messages conveyed, understand, and take purchase actions. The results of this study are similar to research conducted by [30] which examines Syariah banking education and the strategies that will be carried out by Syariah banks. This result strengthens the statement put forward by [2], [3] which shows that public knowledge about banks in Muslim countries is still low.

\section{Conclusion}

Marketing communication has a positive and significant effect on customer awareness of Syariah banks. This means that the better the marketing communication carried out by the Financial Services Authority, the Syariah Banking Association, and the Syariah bank will improve their understanding of Syariah banks.. Based on the hierarchy-of-effects stage, the stages of customers who get information about Syariah banks are processing the information, getting to know Syariah banks and their products, understanding, liking, choosing, and using Syariah bank products. Most students know about Syariah banks and obtain information about Syariah banks from lecture materials delivered by lecturers, websites, seminars, advertisements, and from their families. The research also shows that most students are still at the cognitive stage. 


\section{Implications}

Marketing communication is needed to build awareness of Indonesian people who are mostly Muslims to use Syariah banking products. The results showed that advertising is a medium that provides a lot of information for students to find out about Syariah banking. The Financial Services Authority, the Syariah Banking Association, and the Syariah bank should be able to intensify the use of advertisements and design good advertisements so that they are easily understood by consumers and can build customer awareness. Advertisements also inform products and services as well as the advantages of using Syariah banks, thereby increasing customer knowledge and increasing the intention to use Syariah banks in each of their financial transactions. The introduction of Syariah banking can also be carried out for children starting from the elementary school level through various activities including socialization, activities like saving money at school, as well as Corporate Social Responsibility activities carried out in schools.

\section{References}

[1] Financial Service Authority, "Sharia Banking Statistics 2016," Jakarta, 2016. doi: 10.1017/CBO9781107415324.004.

[2] M. M. H. Abou-Youssef, W. K. E. Abou-Aish, and N. El-Bassioun, "Effects of religiosity on consumer attitudes toward Islamic banking in Egypt," 1994. doi: 10.1108/02652323199400002.

[3] J. Bley and K. Kuehn, "Conventional Versus Islamic Finance : Student Knowledge and Perception,” Int. J. Islam. Financ. Serv., vol. 5, no. 4, 2003.

[4] C. Erol, E. Kaynak, and E. Radi, "Conventionel and Islamic Banks:patronage Behavior of Jordanian Costumers," Int. J. Bank Mark., vol. 8, no. 4, pp. 25-35, 1990, doi: https://doi.org/10.1108/02652329010004231.

[5] H. G. Rammal and R. Zurbruegg, "Awarenss of Islamic Banking Products Among Muslims: The Case of Australia," J. Financ. Serv. Mark., vol. 12, no. 1, pp. 65-74, 2007, doi: 10.1017/CBO9781107415324.004

[6] R. Jabaly, S. Al Ameri, and W. A. Ghoul, "Islamic Banks' Marketing and Communication Tactics : Towards a Better Reception and Perception," J. Islam. Econ. , Bank. Financ., vol. 9, no. 3, pp. 149-176, 2013, doi: 10.12816/0001616.

[7] A. G. Awan and A. Maliha, "Consumer Behavior Towards Islamic Banking in Pakistan,” Eur. J. Account. Audit. Financ. Res., vol. 2, no. 9, pp. 42-65, 2014.

[8] J. Ahmad, "The Role of Public Relations in Promoting Islamic Products Globally: The Malaysian Experience," J. Islam. Stud. Cult., vol. 2, no. 3, pp. 63-81, 2014, doi: 10.15640/jisc.v2n3a4.

[9] K. L. Keller, "Mastering the Marketing Communications Mix: Micro and Macro Perspectives on Integrated Marketing Communication Programs," J. Mark. Manag., vol. 17, no. 7-8, pp. 819-847, 2001, doi: 10.1362/026725701323366836.

[10] A. Hassan, A. Chachi, and S. A. Latiff, "Islamic Marketing Ethics and Its Impact on Customer Satisfaction in the Islamic Banking Industry," Islam. Econ, vol. 21, no. 1, pp. 22-46, 2008, doi: 10.12816/0019139.

[11] M. Ahamedullah, "Islamic marketing ethics and its application in Islamic banking industry," Second Int. Symp., pp. 71-78, 2015.

[12] M. Arham, "Islamic perspectives on marketing," J. Islam. Mark., vol. 1, no. 2, pp. 149164, 2010, doi: 10.1108/17590831011055888.

[13] P. Kotler and K. L. Keller, Marketing Management" Global Edition, 15th ed. England: 
Pearson Education Limited, 2016.

[14] M. Arham, "An Empirical Analysis Of Marketing Activities in Indonesian Islamic Banking Industry," Durham University, 2012.

[15] W. D. Hoyer and S. P. Brown, "Effects of Brand Awareness on Choice for a Common, Repeat-Purchase Product," J. Consum. Res., vol. 17, no. 2, p. 141, 1990, doi: 10.1086/208544.

[16] R. Pappu, R. W. Cooksey, and P. G. Quester, “Consumer-based brand equity: improving the measurement - empirical evidence," J. Prod. Brand Manag., vol. 14, no. 3, pp. 143 154, 2005, doi: 10.1108/10610420510601012.

[17] J. Sasmita and N. M. Suki, "Young consumers' insights on brand equity: Effects of brand association, brand loyalty, brand awareness, and brand image," Int. J. Retail Distrib. Manag., vol. 43, no. 3, pp. 276-292, 2015.

[18] L. Percy and J. R. Rossiter, "A model of brand awareness and brand attitude advertising strategies," Psychol. Mark., vol. 9, no. 4, pp. 263-274, 1992, doi: 10.1002/mar.4220090402.

[19] K. L. Keller, Strategic brand management: Building, Measuring, and Managing Brand Equity, 4 th Globa. Pearson, 2013.

[20] Y.-H. Wang and C.-F. Tsai, "The Relationship between Brand Image and Purchase Intention: Evidence from Award Winning Mutual Funds," Int. J. Bus. Financ. Res., vol. 8, no. 2, pp. 27-40, 2014, doi: 10.1016/s0262-1762(00)90203-7.

[21] J. R. Smith, D. J. Terry, W. R. Louis, and D. Kotterman, "The Attitude - Behavior Relationship in Consumer Conduct: The Role of Norms, Past Behavior, and SelfIdentity," J. Soc. Psychol., vol. 148, no. 3, pp. 311-333, 2008.

[22] K. Hutter, J. Hautz, S. Dennhardt, and J. Füller, "The impact of user interactions in social media on brand awareness and purchase intention: The case of MINI on Facebook," J. Prod. Brand Manag., vol. 22, no. 5, pp. 342-351, 2013, doi: 10.1108/JPBM-05-2013-0299.

[23] D. Howard and T. Barry, "A review and critique of the hierarchy of effects in advertising," Int. J. Advert., vol. 9, no. 2, pp. 121-135, 1990, [Online]. Available: http://dx.doi.org/10.1080/02650487.1990.11107138.

[24] J. F. Hair, W. C. Black, B. J. Babin, and R. E. Anderson, Multivariate data analysis, Seventh ed. New York: Pearson, 2010.

[25] P. Gerrard and J. Barton Cunningham, "Singapore's undergraduates: How they choose which bank to patronise," Int. J. Bank Mark., vol. 19, no. 3, pp. 104-114, 2001, doi: 10.1108/02652320110388531.

[26] P. J. Peter and J. C. Olson, Consumer Behavior Marketing Strategy, Ninth edit. New York, USA: McGraw-Hill, 2010.

[27] S. A. Hakim, I. Al-jubari, and O. K. Bhatti, "Advertising of islamic banking products," Advert. Islam. Bank. Prod., vol. 1, no. 2, pp. 60-70, 2011.

[28] P. Gerrard and J. Barton Cunningham, "Islamic banking: A study in Singapore," Int. J. Bank Mark., vol. 15, no. 6, pp. 204-216, 1997, doi: 10.1108/02652329710184433.

[29] P. A. Fadahunsi and D. S. Kargwell, "Social Media, Consumer Behavior and Marketing Strategy: Implications of 'Halal' on Islamic Marketing Operations," J. Small Bus. Entrep. Dev., vol. 3, no. 1, pp. 36-43, 2015, doi: 10.15640/jsbed.v3n1a4.

[30] A. H. A. Hamid and N. A. M. Nordin, "A Study on Islamica Banking Education and Strategy for The New Millenium - Malaysian Experiance," Int. J. Islam. Financ. Serv., vol. 2, no. 4, pp. 1-10, 2001. 